\title{
University Of Ilorin Final Year Students' Experience In Practice Teaching Exercise
}

\author{
Musa Siddiq Abdullahi \\ University of Ilorin \\ Correspondence concerning this article should be addressed to Musa Siddiq Abdullahi, Department of \\ Arts Education, Faculty of Education, University of Ilorin, P.M.B. 1515, Ilorin, 240003, Nigeria. E-mail: \\ alfulaty2013@gmail.com \\ Musa Salisu \\ University of Ilorin \\ Correspondence concerning this article should be addressed to Musa Salisu, Department of Arts \\ Education, Faculty of Education, University of Ilorin, P.M.B. 1515, Ilorin, 240003, Nigeria.
}

\begin{abstract}
Practice teaching is a vital aspect of the teacher preparatory program in teacher training institutions. This study examined the University of Ilorin final year students' experience in a practice teaching exercise. It made use of descriptive survey research design. The population for this study were all students of the Faculty of Education, University of Ilorin, Ilorin, Nigeria. The researchers' self-developed questionnaire with a reliability coefficient of 0.63 was used for data collection while the data collected were analysed using descriptive statistics of mean and standard deviation and inferential statistics of independent t-test. It was found that during the course of practice teaching exercises, student-teachers acquired skills which enabled them to use a variety of teaching methods, and instructional resources, improved their skills in tests construction, scoring and recording, built their teaching confidence and presentation, among others. However, student-teachers were faced with a number of challenges in the course of lesson presentation during practice teaching. It was, therefore, recommended among others, that student-teachers should not perceive their personality and logical presentation of instructional objectives as challenges but rather should embrace and exploit it to improve and widen their (cognitive) domains.
\end{abstract}

Keywords: education, teacher, teaching, practice teaching, experience, student-teacher

Teaching is an exciting and rewarding activity but like other professions it is demanding. It requires teachers to clearly understand what should be done to bring about the most desirable learning in the learners and to be highly proficient in the skills necessary to carry out these tasks (Kanno, 2013) Teacher education programs in consonance with various levels of education, i.e., NCE, B.Ed. and M.Ed., have been introduced at colleges and universities. All the teacher training institutions not only impart theoretical but also practical knowledge and skills in teaching different subjects to prospective teachers. At the end of the session, practice teaching is carried out as a practical application of the theoretical understanding about different teaching methods. It is generally of one-month duration (Yusuf, 2000).

Practice teaching is a vital aspect of the teacher preparatory program in teacher training institutions and in faculties of Education in the Nigerian universities (Okobia, Augustine, Osagie, 2013). According to Afolabi (2010), the objectives expose student-teachers to the essence of teaching and professional work in the educational sphere with the targets of student-teachers exposing to some sort of preliminary training, teaching methodology and the means of effective teaching. Overschie, Wayenburg, Vries, \& Pujadas (2006) assumed that the positive aspect of the practice teaching is to give meaning to 
accomplishment to student-teachers as they train to obtain ability, gain confidence and step up their classorganizing skills.

In the Colleges of Education and Universities (with an education program), practice teaching exercise is a compulsory course for final year students of the Faculty of Education. The practice teaching exercise is a 6-week program, which is a co-operative venture involving both the student-teachers and supervisors (usually academic staff of the Faculty of Education). The practice teaching exercise is the equivalent of industrial training in the Faculties of Engineering, Sciences and other professions. Subjects in curriculum and teaching methods offered in the Bachelor of Education program are intended to prepare student teachers in the pedagogical skills in specific subjects (Okobia, Augustine, Osagie, 2013). Lu (2010), as an educator, is of the opinion that the theoretical aspect concerns theoretical knowledge acquisition in the class while the practical aspect emphasises all the parameters of pre-service contact with the act of teaching in the class. Links between theory and practice are emphasized in education programs so that students can draw close professional links between the universities and the secondary schools where they are prepared to function as teachers (Okobia, Augustine, Osagie, 2013).

Yusuf (2006) considers that the knowledge and skills acquired are shown before examiners who provide feedback so as to enrich their practice before they are finally evaluated. According to Perry (2004), practice teaching is exciting but challenging. It is against this back-drop that this study examined the challenges faced by student-teachers during the practice teaching exercise. Although practice teaching is a vital component in teacher preparation, the practice teaching role is still dialectical among scholars and educators (Peker, 2009).

\section{Materials}

Practice teaching is the practical aspect of teacher education. According to the (UNESCO, 2002) practice teaching is an indispensable component of teacher education, which is capable of making the potential teacher fit well into the teaching profession. Jekayinfa (2001) noted that sound professional preparation is necessary for success in teaching. Teaching professionalism cannot be acquired overnight, it needs adequate preparation and practical work. Ulaah and Farouq (2008) considered practice teaching as the main quality control measure in the preparation of teachers. Adeyanju (2006) viewed practice teaching as an exercise that gives the teacher trainees opportunity of putting into practice all they have gained during their exposure to different principles and courses. It is the field that permits the application of the theoretical to practical.

According to Adesina (2005), practice teaching is one of the first innovations in teacher education. It is a compulsory course in all teacher preparatory programs. Practice teaching is a core aspect of teacher education, which is designed for training and testing the teacher trainees' mastery of teaching skills. Bhargava (2009) described practice teaching as a time when all learned concepts have to be applied in real life situations successfully. It provides improvement to teacher trainees in terms of forming positive attitudes towards the teaching profession, gaining teaching skills, applying theoretical knowledge to the instructional settings of the profession and professional proficiency. This is because student teachers gain their first teaching experience, which will be useful during their professional life. Cetin (2013) viewed practice teaching as the application of professional knowledge and understanding of the learners, curriculum, teaching and learning environment so as to promote learning. For teacher trainees to understand the relationship between theory and practice in teacher education, practice teaching has a crucial role to play.

Ulaah and Farouq (2008). pointed out that the new trends in teacher education programs focus on the investigation of the problems associated with the training of student-teachers. So, the study programs of teacher education are programmed to include interesting activities that provide students with a realistic experience for future teaching (Jones, Foster, Groves, Parker, Straker \& Rutler, 2004).

However, Farrell (2008) declared that the most important factors that affect student-teachers' practicum experience are the cooperative teachers and peers who spend most of the time with the studentteacher. In this regard, Otuka (2008) reported that when student-teachers have high level of pressure during a practicum experience they do not engage positively in the teaching process. In addition to practicum stress, supervision and administrative work-load are examples of practicum defect issues. This study therefore, examined the practice teaching experience of the University of Ilorin Final Year students in terms of challenges and the panacea.

\section{Methods}

The general purpose of this study was to examine University of Ilorin final year students' experience in practice teaching exercise. Specifically, this study examined the skills acquired by student-teachers in 
the course of their practice teachings exercise; the challenges encountered by student-teachers and the difference in the skills acquired; and challenges encountered by male and female student-teachers during their practice teaching exercise. The following research questions were answered:

1. What skills do student-teachers acquire during the course of their practice teachings exercise?

2. What are the challenges encountered by studentteachers in the course of their practice teaching exercise?

The following null hypotheses were postulated and tested:

1. There is no significant difference in the skills acquired by male and female student-teachers during their practice teaching exercise.

2. There is no significant difference in the challenges encountered by male and female student-teachers during their practice teaching exercise.

\section{Procedure}

This study made use of a descriptive survey research design. The population consisted of all the students of the Faculty of Education at the University of Ilorin in, Nigeria, with the target population all final year students in all the Departments in the Faculty of Education. A total number of 200 students were sampled using multiphase sampling techniques. At the first phase, a purposive sampling technique was used to select 400 level students in the first semester of the 2015-2016 academic session: this constituted the respondents as they had experienced and passed through the practice teaching exercise. At the second phase, a simple random sampling technique was used to select 20 students from each of the departments and the Institute of Education in the faculty and this made a total of 200 final year students sampled across all the nine Departments and Institute of Education in the Faculty. Researchers' designed a questionnaire structured in a four-response type, with strongly agree $(\mathrm{SA})$, agree $(\mathrm{A})$, disagree $(\mathrm{D})$ and strongly disagree (SD), and a reliability coefficient of 0.63 was used for data collection. See Appendix A for the questionnaire items. Descriptive statistics of mean and standard deviation were used to answer the research questions while the hypotheses postulated were tested using the inferential statistics of independent t-test at the 0.05 level of significance.

\section{Results}

Out of 200 final year students that took part in this study, 110 (55\%) of the respondents were male and 90 (45\%) were female.
In answering research questions, a cut-off score of 2.50 was used as the baseline for determining participants' responses since the questionnaire items were structured in a four-response-type.

Research Question One: What skills do student-teachers acquired during the course of their practice teachings exercise?

As shown in Table 1, no item has a mean score below 2.50. This implies that during the course of the practice teaching exercise, student-teachers acquired skills which enabled them to use a variety of teaching methods and instructional resources, identify and apply an appropriate teaching method for a particular class, improved their skills in test construction, scoring and recording, built their teaching confidence and presentation, among others.

Research Question Two: What are the challenges encountered by student-teachers in the course of their practice teachings exercise?

As shown in Table 2, ranked first, second, up to the fifth are items whose mean scores are above 2.50 . This implies that planning lessons from the work scheme, teacher's personality (Dressing \& Emotion) was stressful during practice teaching the organization of knowledge which must be presented in sequential order, the logical presentation of instructional objectives during practice teaching as well as consistent writing of lesson plans were the challenges

Table 1

Mean and rank order of participants' responses on the skills acquired during the course of practice teaching exercises

\begin{tabular}{|c|c|c|c|c|}
\hline SN & Items & Mean & Rank & Remark \\
\hline 4 & $\begin{array}{l}\text { I learned to use a variety of } \\
\text { teaching methods }\end{array}$ & 2.90 & $1^{\text {st }}$ & Acquired \\
\hline 1 & $\begin{array}{l}\text { The exercise helped me } \\
\text { identify and apply an } \\
\text { appropriate teaching method } \\
\text { for a particular class }\end{array}$ & 2.89 & $2^{\text {nd }}$ & Acquired \\
\hline 5 & $\begin{array}{l}\text { I learned to use a variety of } \\
\text { instructional resources }\end{array}$ & 2.83 & $3^{\text {rd }}$ & Acquired \\
\hline 6 & $\begin{array}{l}\text { The exercise improved my } \\
\text { classroom management skills } \\
\text { through the feedback from the } \\
\text { supervisors }\end{array}$ & 2.69 & $4^{\text {th }}$ & Acquired \\
\hline 7 & $\begin{array}{l}\text { The exercise improved my } \\
\text { skills in test construction, } \\
\text { scoring and recording }\end{array}$ & 2.63 & $5^{\text {th }}$ & Acquired \\
\hline 8 & $\begin{array}{l}\text { The exercise enabled me to } \\
\text { identify students with learning } \\
\text { difficulties and give special } \\
\text { attention to them }\end{array}$ & 2.60 & $6^{\text {th }}$ & Acquired \\
\hline 2 & $\begin{array}{l}\text { The exercise built my teaching } \\
\text { confidence and presentation }\end{array}$ & 2.58 & $7^{\text {th }}$ & Acquired \\
\hline 3 & $\begin{array}{l}\text { The exercise helped me to } \\
\text { master the subject matter }\end{array}$ & 2.56 & $8^{\mathrm{h}}$ & Acquired \\
\hline
\end{tabular}


Table 2

Mean and rank order of participants' responses on the challenges encountered during the course of practice teaching exercise

\begin{tabular}{|c|c|c|c|c|}
\hline SN & Items & Mean & Rank & Remark \\
\hline 1 & Planning lesson from the scheme of work is a challenge in practice teaching & 2.59 & $1^{\text {st }}$ & Encountered \\
\hline 12 & Teacher's personality is stressful during practice teaching & 2.59 & $1^{\text {st }}$ & Encountered \\
\hline 6 & $\begin{array}{l}\text { Organization of knowledge presented in sequential order during practice teaching is } \\
\text { tasking }\end{array}$ & 2.56 & $2^{\text {nd }}$ & Encountered \\
\hline 3 & I can't present statement of instructional objectives logically during practice teaching & 2.54 & $3^{\text {rd }}$ & Encountered \\
\hline 2 & Writing lesson plan adequately challenged me during my practice teaching & 2.51 & $4^{\text {th }}$ & Encountered \\
\hline 4 & $\begin{array}{l}\text { I do not usually present statement of behavioral objectives logically during practice } \\
\text { teaching }\end{array}$ & 2.47 & $5^{\text {th }}$ & Not Encountered \\
\hline 5 & Use of appropriate content (topic \& sub-topic) during practice teaching is taxing & 2.46 & $6^{\text {th }}$ & Not Encountered \\
\hline 7 & Indication of entry behavior during practice teaching is taxing & 2.36 & $7^{\text {th }}$ & Not Encountered \\
\hline 8 & Planning for suitable students' activities during practice teaching is taxing & 2.34 & $8^{\text {th }}$ & Not Encountered \\
\hline 9 & Indication of adequate lesson during practice teaching is taxing & 2.30 & $9^{\text {th }}$ & Not Encountered \\
\hline 10 & Time allocated for subject during practice teaching is a great challenge & 2.29 & $10^{\text {th }}$ & Not Encountered \\
\hline 11 & Handling individual differences during practice teaching is a great challenge & 2.29 & $10^{\text {th }}$ & Not Encountered \\
\hline
\end{tabular}

encountered by student-teachers in the course of their practice teaching exercise.

However, the logical presentation of behavioural objectives the use of appropriate content (topic \& subtopic), the indication of entry behaviour and planning for suitable students' activities during practice teaching exercise among others were not found to be challenges encountered by student-teachers in the course of their practice teaching exercise.

\section{Hypotheses Testing}

Hypotheses postulated were tested at the 0.05 alpha level.

Hypothesis One: There is no significant difference in the skills acquired by male and female studentteachers during the practice teaching exercise

Table 3 shows the $t$-value of 1.322 obtained with a p-value of 0.071 computed at the 0.05 alpha level. Since the p-value of 0.07 is greater than the 0.05 alpha level, the null hypothesis one is retained. This implies that there is no statistically significant difference in the skills acquired by male and female studentteachers during the practice teaching exercise.

Hypothesis Two: There is no significant difference in the challenges encountered by male and female student-teachers during the practice teaching exercise

Table 4 shows the t-value of 1.424 obtained with a p-value of 0.063 computed at the 0.05 alpha level. Since the p-value of 0.06 is greater than the 0.05 level of significance, null hypothesis two is retained. This implies that there is no statistically significant difference in the challenges encountered by male and female student-teachers during the practice teaching exercise.
Discussion

Findings from this study revealed that studentteachers acquired skills which enabled them to use a variety of teaching methods and instructional resources, identify and apply an appropriate teaching method for a particular class, improve their classroom management skills through the feedback from their supervisors, improve their skills in test-construction, scoring and recording, enable them to identify students with learning difficulties, build their teaching

Table 3

T-test statistics showing the difference in the skills acquired by male and female student-teachers the practice teaching exercise

\begin{tabular}{|c|c|c|c|c|c|c|c|}
\hline Gender & $\mathrm{N}$ & Mean & S.D. & $\mathrm{df}$ & $\mathrm{t}-_{\text {cal }}$ & Sig. & Remark \\
\hline Male & 110 & 2.245 & 1.323 & & & & \\
\hline & & & & 198 & 1.322 & 0.071 & NS \\
\hline Female & 90 & 2.121 & 1.041 & & & & \\
\hline
\end{tabular}

Note. Insignificance at $\mathrm{p}>0.05$

Table 4

T-test statistics showing the difference in the challenges encountered by male and female student-teachers during the practice teaching exercise

\begin{tabular}{|c|c|c|c|c|c|c|c|}
\hline Gender & $\mathrm{N}$ & Mean & S.D. & $\mathrm{df}$ & $\mathrm{t}-_{\mathrm{cal}}$ & Sig. & Remark \\
\hline \multirow[t]{2}{*}{ Male } & 110 & 2.352 & 1.232 & & & & \\
\hline & & & & 198 & 1.424 & 0.63 & NS \\
\hline Female & 90 & 2.003 & 1.021 & & & & \\
\hline
\end{tabular}

Note. Insignificance at $\mathrm{p}>0.05$ 
confidence, presentation and improve their skills in the mastery of their subject matter. This outcome supports Jekayinfa, Yahaya, Yusuf, Ajidagba, Oniye, Oniyangi, \& Ibrahim (2012) whose findings revealed that the skills acquired by the students from practice teaching enabled them to be more competent in their classroom instruction.

The results from this study revealed that the challenges encountered by student-teachers during the course of practice teaching exercise include lesson-plans from the scheme of work; organization of knowledge which must be presented in sequential order, teacher's personality (Dressing \& Emotion) being stressful during practice teaching; logical presentation of instructional objectives during practice teaching as well as consistent writing of lesson plans. This latter finding agrees with Achuoye (2007), who found that majority of students-teachers having difficulties in writing lesson plans.

However, as revealed from the findings, the logical presentation of behavioural objectives, the use of appropriate content (topic \& sub-topic) and the indication of entry behaviour and planning for suitable students' activities were not found as challenges encountered by student-teachers in the course of their practice teaching exercise. This outcome disagrees with Dagnew (2011), whose findings revealed that the presentation of behavioural objectives and the use of appropriate content were challenges encountered by majority of student teachers.

This study showed that there is no significant difference in the skills acquired by male and female student-teachers during the practice teaching exercise. The results also revealed that there is no significant difference in the challenges encountered by male and female student-teachers during the practice teaching exercise. This outcome is in line with Jekayinfa (2001) who found no significant statistical differences in the skills acquired and challenges encountered by student teachers based on gender.

\section{Conclusion}

Based on the findings from this study, it can be concluded that student-teachers acquired skills in the use of variety of instructional resources, adopting appropriate teaching methods for the classroom instruction, building of self-confidence and identification of variety of students with learning difficulties during the practice teaching exercise. It can also be concluded that among the challenges encountered by student-teachers during the practice are consistent writing of lesson plan with organization of knowledge which must be presented in sequential order, teacher's personality (Dressing \& Emotion) being stressful during practice teaching as well as logical presentation of instructional objectives. In addition, no discrepancy or differences exists in the skills acquired and challenges encountered by male and female student-teacher during the practice teaching exercise.

Based on the findings and conclusion drawn from this study, it is therefore recommended that studentteachers should not perceive their personality and logical presentation of instructional objectives as challenges but rather should embrace and exploit them to improve and widen their (cognitive) domains. Student-teachers should understand and realize that consistent and up-to-date writing of lesson plans is a way to not only guide themselves as teachers, but also help in the logical and sequential presentation of their subject matters. University management should train the students before being sent to the field for teaching practice. Also, policy makers should extend the periods used for practice teaching in the Nigerian universities for effective training.

\section{References}

Achuoye, K. A. (2007). Microteaching: A practice on teaching skills. Port Harcourt, Nigeria: Pearl Publishers.

Adesina, S. (2005). Growth without development: Nigerian educational experience 1914-2004. Abeokuta, Nigeria: Educational Industries.

Adeyanju,F.B. (2006). Repositioning teacher education for National development and technological breakthrough. Nigeria Journal of Science and Educational Research, 1(1), 6-7.

Afolabi, A. O. (2010). The concept of microteaching. In U. I. Aleiburu (Ed.), Micro teaching for teachers in training-new approach with practicum (pp. 59-71). Lagos, Nigeria: Jinsalaam Press.

Bhargava, A. (2009). Comparative study of teaching skills in in-service teachers. Retrieved on June 8th, 2016 from www.itdl.org/journal/Aug_09/articleO2

Cetin, S. (2013). The effect of micro-teaching applications that are used in practice teaching course on classroom management self-efficacy convictions of students. International Journal of Academic Research, 5(4), 375-379. Retrieved on April 1st, 2016 from search.ebscohost.com/login. aspix\%3Fd

Dagnew, A. (2011). Reflective effects of micro-teaching and field experiences on pre-service teachers. Retrieved on April 21st, 2016 from vetrieducation. com/wp.content/upload

Farrell, M. A. (2008). Researching early childhood 
student teachers: Life histories and course experience. International Journal of Early Childhood, 32, 34-40.

Jekayinfa, A. A. (2001). Rudiments of practice teaching. Retrieved on March 18th, 2016 from www.unilorin. edu.ng/publications/je

Jekayinfa, A. A., Yahaya, L. A., Yusuf, A., Ajidagba, U. A., Oniye, A. O., Oniyangi, S. O., \& Ibrahim, T. O. (2012). Lecturers' assessment of practice teaching exercise. Journal of Education and Practice, 3(4). Retrieved from www.iiste.org

Jones, M., Foster, R., Groves, J., Parker, G., Straker, K., \& Rutler, T. (2004). How do mentors know what they know? An investigation into mentors' professional knowledge base. Paper presented at the meeting of British Educational Research Association Conference, UMIST, Manchester, UK.

Kanno, T. N. (2013). Transferability of set induction and questioning skills of microteaching to actual practice teaching. Abuja, Nigeria: Nigerian Educational Research and Development Centre.

$\mathrm{Lu}, \mathrm{H}$. L. (2010). Research on peer coaching in preservice teacher education. A Review of Literature, Teaching and Teacher Education, 26, 748-753.

Okobia, E. O., Augustine, O. E., \& Osagie, R. O. (2013). An analysis of the perceived challenges faced by student-teachers during teaching practice exercise. Journal of Education and Practice, 11(4), 7-12.

Otuka, J. O. E. (2008). Implementation issues in teacher education: Problems and prospects. Paper presented at the 7th Annual National Conference of National Association for Research Development (NARD), FCT College of Education, Zuba-Abuja, Nigeria.

Overschie, M., Wayenburg, A., Vries, P., \& Pujadas, M. (2006). Microteaching: Effective knowledge transfer for sustainable technological innovation. Paper presented at the International Conference on Engineering Education in Sustainable Development, EESD, Lyon, France. Retrieved from http://upcommons.upc.edu/bitstream/ handle/2117/6651/ Pujadas\%20MICROTEACHING. pdf

Ulaah, S. Z, \& Farouq, R. A. (2008). Effectiveness of teacher education programs in developing teaching skills for secondary level. Journal of Quality and Technology Management, 6. Retrieved from http:// journals.pu.edu.pk/journals/index.php/jqtm/index UNESCO. (2002). ICT in teacher education: A planning guide. Paris, France: UNESCO.

Yusuf, M. O. (2006). Influence of video-taping and audio-taping feedback modes on studentteachers' performance in micro-teaching. Malaysia Journal of Instructional Technology. Retrieved on June 2nd, 2016 from www.unilorin.edu.ng/newsite2/EDUCAT

Yusuf, M. O. (2000). Instructional media for effective practice teaching. In I. A. Idowu (Ed.), Principles of teaching practice (pp. 64-72). Ilorin, Nigeria: University of Ilorin. 


\section{Appendix A}

Department of Arts Education

Faculty of Education, University of Ilorin, Ilorin

Questionnaire on University of Ilorin Final Year Students' Experience in Practice Teaching Exercise

Dear respondents,

This questionnaire was designed to elicit information on the purpose of this study. The information supplied will be treated with utmost confidentiality.

Yours faithfully

The Researchers

\section{Section A: Personal Information}

Instruction: Please provide answers to the items in the spaces provided or put a tick ( ) in the appropriate column.

\section{Demographic Data}

1. Gender: Male ( ) Female( )

2. Department:

Section B:

Instruction: Please tick the option as appropriate based on your experience during the practice teaching exercise on the following items:

\begin{tabular}{|c|c|c|c|c|c|}
\hline SN & Student-Teachers' skills Acquired from Practice Teachings Exercise & SA & A & D & SD \\
\hline 1 & $\begin{array}{l}\text { The exercise helped me identify and apply an appropriate teaching method for a particular } \\
\text { class }\end{array}$ & & & & \\
\hline 2 & The exercise built my teaching confidence and presentation & & & & \\
\hline 3 & The exercise helped me to master my subject matter & & & & \\
\hline 4 & I learned to use a variety of teaching methods & & & & \\
\hline 5 & I learned to use a variety of instructional resources & & & & \\
\hline 6 & $\begin{array}{l}\text { The exercise improved my classroom management skills through the feedback from my } \\
\text { supervisors }\end{array}$ & & & & \\
\hline 7 & The exercise improved my skills in tests construction, scoring and recording & & & & \\
\hline 8 & $\begin{array}{l}\text { The exercise enabled me to identify students with learning difficulties and give special } \\
\text { attentions to them }\end{array}$ & & & & \\
\hline No & The challenges faced by student-teachers during practice teaching exercise & SA & A & D & SD \\
\hline 1 & Planning lesson from the scheme of work is a challenge in practice teaching & & & & \\
\hline 2 & Writing lesson plans adequately challenged me during my practice teaching & & & & \\
\hline 3 & I can't present a statement of instructional objectives logically during practice teaching & & & & \\
\hline 4 & $\begin{array}{l}\text { I do not usually present a statement of behavioural objectives logically during practice } \\
\text { teaching }\end{array}$ & & & & \\
\hline 5 & $\begin{array}{l}\text { Organization of knowledge presented in sequential order during practice teaching is } \\
\text { taxing }\end{array}$ & & & & \\
\hline 6 & Use of appropriate content (topic \& sub-topic) during practice teaching is taxing & & & & \\
\hline 7 & Indication of entry behaviour during practice teaching is taxing & & & & \\
\hline 8 & Planning for suitable students' activities during practice teaching is taxing & & & & \\
\hline 9 & Indication of adequate lesson during practice teaching is taxing & & & & \\
\hline 10 & Time allocated for subject during practice teaching is a great challenge & & & & \\
\hline 11 & Handling individual differences during practice teaching is a great challenge & & & & \\
\hline 12 & Teacher's personality (Dressing \&Emotion) is stressful during practice teachir & & & & \\
\hline
\end{tabular}




\section{Appendix B}

\section{List of Departments}

1. Department of Arts Education

2. Department of Social sciences Education

3. Department of Science Education

4. Department of Educational Management

5. Department of Counsellor Education

6. Department of Educational Technology

7. Department of Adult and Primary Education

8. Department of Human Kinetics Education

9. Department of Health Promotion and Environmental Health Education

10. Institute of Education 